\title{
The Turkic Elites of Russia: Experience of Ethno-Cultural Interaction the End of XIX-1920s
}

\author{
Krasovitskaya T* \\ ${ }^{1}$ Licenciatura em Física, Federal Institute of São Paulo, Brazil \\ ${ }^{2}$ Faculdade de Letras da Universidade do Porto, Portugal \\ ${ }^{3}$ Coordenadoria de Formação Pedagógica, Federal Institute of São Paulo, Brazil
}

*Corresponding author: Tamara Krasovitskaya, Doctor of Historical Sciences, Professor, Institute of Russian History of the Russian Academy of Sciences, Russia, Email: tkrasovitskaya@mail.ru

\section{Abstract}

The participation of the Turkic elites in the modernization processes is not a stock of facts, but a creative process. The vectors of cross-cultural interaction in it are diverse and, most importantly, are determined by specific circumstances. Let's take at least their history of education and specialization of training. This important resource explains the vectors of interaction between the Turkic elites and the modernization processes.

Keywords: Turkic Elites; Modernization; Vectors of Cross-Cultural Interaction; Education and Training Specialization

\section{Mini Review}

The participation of the Turkic elites in the processes of modernization is not a warehouse of facts, but a creative process. The vectors of intercultural interaction in it are diverse and, most importantly, are conditioned by specific circumstances. Take, for example, their educational history and teaching specialization. This important resource explains the vectors of interaction of the Turkic elites with modernization processes.

Many could not (but wanted!) To get an education at home but most of them got it abroad. They strove to study at law, economics and other social faculties. Political sciences at that time were considered a sub discipline of jurisprudence, at least in Russia. The Faculty of Law of St. Petersburg University, which V. Lenin graduated as an external student, remained one of the best centers of political research in Russia. One of the leaders of the Turkic elite I. Gasprinsky carefully studied the experience of the French education system From the beginning of the 20th century, Russian Muslims began to study in France. In 1910, up to 500 Muslim students studied in Paris, of which up to 300 were Turks. The group of Muslims from Russia consisted of 10 people, two of them were women. Most of the Turkic students studied in Germany [1].

Russian émigré scientists taught in Paris. Liberal professors E.V. de Roberti together with M. Kovalevsky created the Russian Higher School of Social Sciences. Kovalevsky interpreted Russian political practices within the framework of the "theory of social progress." The civil studies were taught by Yu.S. Gambarov, professor of political economy and statistics at Moscow University A.I. Chuprov and N.A. Kablukov, Historian P.G. Vinogradov, Economist M.I. Tugan-Baranovsky, literary historian S.A. Vengerov, ethnographer F.K. Wolf, philologist and literary critic E.V. Anichkov, historian of law S.A. Kotlyarevsky and others Of course, the content of knowledge acquired by Turkic students is a separate and important topic. But the 
interest of Turkic students in the perception by Western peoples of the question of power: should a person submit to the collective will or vice versa, grew. The French instinct decided: power does not belong to anyone; it is not the state that is important, but the equality of all. English instinct led to the fact that power belongs to the individual. In the end, it benefits everyone. Both were called democracy, but in a completely different sense of the word. German instinct said: power belongs to the whole. A separate person serves him as you can see; different countries gave different answers to this question. Thus, the students got an idea of how governments justify their policies by applying certain ideological concepts, judgments and public feelings, religious, confessional ideas, and traditional values of the image.

Knowledge trips took on a significant scale and knowledge acquired a new quality. Ethnic elites traveled abroad for them also because foreign professors provided a more modern interpretation of juridical and legal, for example, knowledge in relation to the reformist aspirations of the Russian Turkic-speaking elites. At the beginning of the 20th century, theologian Muhammad Abdo put forward the concept of reforming Islam, highlighting the importance of acquiring knowledge for social renewal. Abdo's reformatory ideas have been translated into the Tatar language. The book "Muslim Philosophers" was published in Orenburg in 1909. Al-Azhar University in Cairo was very popular Future Tatar philosophers, historians, public and religious figures Z. Kamali, Z. Kadiri, M. Bigi, G. Battal, G. Rasuli studied with Abdo. Two students of Sh. Mardzhani graduated from it: K. Sayfutdinov and A. Yakhudi. After completing a university course, they taught Eastern philosophy in the Turkic department. In Kazan, Sayfutdinov taught a course in Islamic philosophy at the Muhammadiya madrasah for 10 years.

Z. Kamali, after studying natural and mathematical sciences in Istanbul, entered the Faculty of Philosophy of AlAzhar. The deputy director of the madrasah Galiya G. Shnasi, having received his education in al-Azhar, wrote a textbook in Tatar on chemistry many believed that Muslims approached knowledge absolutely not creatively, in everything new they tried to recognize the old, and were indifferent to modern changes. Today's research refutes such notions. And on the eve of 1917, the Kazan censor and church historian P.V. Znamensky believed: Kazan Muslims were drawn to the practices of "Cairo with its European knowledge and secular direction. Young people began to go more to Cairo than to Istanbul. Upon returning from there, young people spread the new science at home educational institutions of a new type in Kazan are now attracting a lot of students - it is clear that they fell in love with the young Tatar generation. The new movement is not against Islam as a necessary nationalist element of life, but it, of course, should significantly weaken the old narrowly religious direction of this life.
The old, obsolete generation of Tatars with its fanatical mullahs and old-method madrasahs lags behind and is obscured by the new demands of the century [2].

In 1909, 63 Tartars studied at the educational institutions of Istanbul: at the university-14, teachers' seminaries-12, secondary educational institutions-20, the sultan's schools-4, city schools-10. mulkiya-i-shahane" F. Karimi studied economics, literature, history, philology, studied Turkish and French. He was especially interested in curricula, preparation of textbooks, and the work of the Ministry of Education. F. Karimi, with the support of his father, intended to continue his education in Europe. In one of the letters, my father showed professional knowledge of foreign education systems: you "probably want to continue your education in one of the European countries at your own discretion. I think that if you are interested in technical specialties, then you should choose Germany, and if you are interested in literature, art, libraries, then you should go to Paris" [3]. Part of the youth, deepening their knowledge of Islamic studies in Istanbul, went to educational institutions of Mecca, Medina and Beirut Until 1917, representatives of a large Turkic ethnic group young Kazakhs A. Gaisin, S. Shanov, D. Kelbaev, M. Turganbaev, A. Mashaev - were educated at Istanbul University. The Turkestan governor A. Samsonov learned from a letter from the Russian embassy in 1910 that in Istanbul about 100 students from Central Asia are studying "the common theses of pan-Islamism and Turkic chauvinism." The embassy reported: "information that agents were sent to Bukhara to spread pan-Islamist propaganda." The security department of 1913 indicated: 250 students from Bukhara alone study in Turkey.

"Everything that was intelligent among these Tatars turned their gaze to the centers of the mental life of Islam Paris, Constantinople and Cairo," stated the imperial structures in 1910 [4]. What follows from this for understanding the experience and trends of ethnocultural interaction of elites?

First, displaced to foreign universities, they perceived knowledge as ideological and symbolic constructs. With their help, the main meaningful general vector was formed: the readiness of the Turkic elites to see the world in the process of changes. The effective practices of social construction of reality, acquaintance with various philosophical theories about interaction with the world and man were comprehended. In 1910, the ethnographer L. Sternberg commented on the training of the Tatars in Cairo: "Here English freedom gave rise to ideas in Islam, which, perhaps, is destined to change the entire psyche of the Muslim world" [5]. Among the Muslims of Russia, the theory of the similarity of the process of creating a Turkic nation to the creation of nation-states in Europe was put forward in 1911 by one of the leaders of the movement during the period of the Russian 
revolution of 1905-1907. Azerbaijani Akhmed bey Agayev. The most important processes that led to the formation of the unity of the Muslim peoples of Russia, he considered cultural and linguistic unity. As a result, a community of Russian Muslims of the Caucasus, Crimea, Kazan and Orenburg was formed, the main institution of which A. Agayev calls schools in the Turkic language, headed by the Muslim intelligentsia [6].

Second, the experience of acquiring university knowledge has turned prominent representatives of the elite into charismatics. This was also facilitated by the fact that in Russian government circles the political function of reforms in education prevailed over the function of education. The politicization of the reforms became the reason for the unpopularity of the humanistic potential of cultural panTurkism. Rising in their origins to the educational attitudes and ideas of I.

Gasprinsky's educational practices were pushed into the background. Pan-Turkism was perceived as a foreign product of the ideological import of the Ottoman Empire. He especially irritated the imperial center. Special circulars of the Ministry of Internal Affairs demanded not to admit to teaching those who received education abroad. On October 7 , 1910, in a secret letter, Stolypin ordered the governors of the outskirts "to take absolutely decisive measures to expel them from the empire" [7].

Stolypin believed that these "foreigners" contribute to the awakening of "narrow national-political consciousness." They "lead to the aggravation of the principles of national isolation and discord." They should be considered "threatening public peace and security", in education - competitors to the public school. S. Maksudi cites data: "During the year, 150 Muslims were searched; more than 70 educational institutions and educational institutions were closed." Attempts to find a unified pan-Islamist movement, he argued, are doomed to failure, because such a phenomenon does not exist. Maksudi criticized the demands of the Special Anti-Muslim Conference (1910) "to prevent the teaching of any general education subjects in confessional schools" [8].

Third, young representatives of the Turkic elites entered adulthood when professional activism was gaining momentum as a way of rebuilding society. The Tatar historian J. Validi wrote: "In the history of the Tatars, there probably was not such a deeply disturbing question for the people's soul as the question of renovating the school" [9].

In Russia, at the turn of the 19th and 20th centuries, a generation of intellectuals who were open to secular education was born. They were among the first to be drawn into the process of change, which was reflected in the way they began to look at themselves and the world around them. The situation was viewed as a preparatory stage for the maturation of management structures. These designs were based on ground that rejected unification.

Fourth, according to their convictions, most of the representatives of the Turkic elites were autonomous federalists. The smaller part was self-styled. Criticism of Russian historiography at the turn of the century and the emphasis on the fact that only the Russian people inhabited Russia, and not a multinational population, for example V. Klyuchevsky, still displeases the Turks, especially the Tatars. In the preface to the first part of the seven-volume history of the Tatars, R. Khakimov notes: "The state was Russian, and the people were Russian. There was no place left for the Tatars and their statehood" [10]. Modern Tatar historians focused their research on the history of the Volga Bulgars, and not on the joint Russian-Tatar or Russian-Turkic past.

February 1917 intensified the dialogue about the federation as a form of the future state, in which it is possible to preserve the common Turkic unity and common cultural resources: language, its instruments, religion, partly, common history. The dialogue proceeded along the line of horizontal links. Horizontal ties raised the issue of ethnic territories and their boundaries.

Fifth, the language problem took center stage in the controversy over school reform. Reformers and conservatives, atheists and religious orthodox, supporters of the national movement and internationalists participated in it in a particularly acute form.

The Muslim school, in addition to the Arabic language, used the Turkic language. It has a long history of formation associated with the emergence of modern Turkic peoples on the historical arena. The Turkic language was not the only one, but it was widespread from the Great Wall to the Caspian Sea and up to Kazan. The Türks had a number of regional features that distinguished it from other versions of this book language, was used as a literary form, gradually absorbing local folk elements, which led to the emergence of local variants of the written language. The Chagatai language played a huge role. A number of ethnic groups found themselves at the center of the intersection of various linguistic practices. In the XVI-XIX centuries. The Old Tatar literary language was already functioning, continuing the tradition of the Turki; there was also literature of various topics. But other native languages were gaining strength and overgrown with their cultural resources. An important role for them was played by the absence of a common secular power for the Turks as a regulator of the process and a customer of cultural products. 
All the elites were fed from sources with different potential for cultural self-affirmation, and acted in a manifest form. The whole of 1917, in fact, was spent on the struggle between the regionalist autonomists (A.-Z. Validov) and the Turkists ( $\mathrm{S}$. Maksudi) the latter are advocating the importance of preserving the common fund of cultural heritage. The autonomists won, they were carried away by career prospects, the creation of their own state structures. The Bolsheviks promised them.

Sixth, a division has formed that directly depends on the political consciousness of the elites. From various versions: "technological modernism" and "modernism of freedom" (according to Yu. Habermas), they chose technologies and practices as they were more familiar to them. Those who followed the Bolsheviks, in fact, embarked on the path of exchanging an ethnocultural resource for an imperious resource. On the path of disinterested use of the explosive potential of ethnic intolerance. Many skillfully moved to the center of events. To Moscow, to the People's Commissariat of Education, to the People's Commissariat for Education, to the structures of the Central Committee of the RCP (b). They supported the Bolshevik pathos, trying to promote their own cultural product with their support various programs, plans, projects, periodicals, etc.

Seventh, it is important that when they found themselves in Moscow in the same structures, they "irradiated" each other from different aspects, both on a regional and general Turkic scale (they grouped around M. Sultangaliev, T. Ryskulov, etc.). But with the formation of Soviet autonomies, they were captivated by the role of local leaders, which strengthened their charisma.

The specificity of this historical experience was the particularly difficult realization of national interests in the Soviet modernization project. The elites insisted on moving towards industrialism relying on their own cultural resources. The native language moved to the center of their attention as politicians $\mathrm{He}$ remained an important link with his native environment. But the language resource, its capabilities in the modernization process and in the language market has not been objectively evaluated from the standpoint of their ability to acquire modern secular knowledge. Professional linguists in school practices have relied on secular knowledge as a factor of social survival and well-being. But the possibilities of a language resource in the modernization process on the language market have not been objectively assessed.

Ethnic elites, while adopting modern practices, continued to value ethnic potential above progressive Soviet goals. In response, Soviet political strategists dubbed these practices "pan-Turkism", "pan-Islamism". Many were repressed on this basis, withdrawn from the real political process.
On the whole, the Soviet government, not opposing the involvement of the Turkic elites into the Soviet continuum, assessed them as second-tier figures. In this context, the institutions and instruments that were formed among the Turkic communities on the basis of their own cultural traditions were assessed as hindering Soviet modernization. What was preserved and defended as the mechanism of this unity was perceived as backwardness. In a simplified sense, the processes were considered in two ways: on the one hand, as a fight against the "excesses" of self-knowledge of various ethnic communities, including "ethnic egoism," on the other, as a stage in the introduction of peoples into a wider and, as it was believed, more cultural space. Social engineering was presented as an activity aimed at including the Turkic ethnic groups in the construction of socialism (the process of modernization). The general goals were thus achieved: the ideological content of the "center" policy determined the content of the historical process. Ethnic differences were taken into account in the implementation of certain transformations, although the issue of ethno cultural autonomy was gradually eliminated by referring to the fact that the Country of Soviets was built as a supranational state. She considered herself the successor of the Enlightenment and the leader of the Progress. Everything suitable for Soviet construction was drawn into its sphere and welcomed. Everything that resisted was stigmatized as "bourgeois", "feudal-bai" remnants, rejected, and later - repressed.

The assessment of the process of modernization of the Turkic ethnic groups, which are still at the junction of tradition and modernity, has a predominantly negative meaning. Cultural losses obscure its positive aspects; devalue goals, values and achievements. Critics speak of the hypothetical possibility of a softer, more humane and tolerant modernization strategy. Such an assessment also contains the inevitable motive of the interethnic and intercivilizational conflict between modernizers and those who are being modernized. But you cannot discount the newly opened interesting laboratory of the fusion of intellectual history and political practice, broad possibilities for comprehending the intricacies of national and Soviet identities.

\section{References}

1. Validov J (1998) Essay on the history of education and literature of the Tatars Kazan. “Iman”, pp: 118-119.

2. Znamensky PV (1910) Kazan Tatars: Typolite.

3. Fatih K (2000) Scientific and biographical collection. Kazan. Rukhiyat, pp: 79.

4. Adam V (2000) Russian Muslims in Istanbul on the eve of the First World War. The Reporting of the Ottoman Periodicals on Russia and Central Asia, Frankfurt am 
Main, pp: 467.

5. Zabutdinov AU, Mukhettinov DV (2007) Russian Muslim Tatars: from the United Nations.

6. Agaev A (1911) Turk galeme. Turk Yurdu 2: 37-42.

7. Adam VS, pp: 467.
8. Zabuttinov A (2003) Fire hydrants. Kazan. Tatar, pp: 95.

9. Validov DC, pp: 106.

10. Rafael H (2002) History of the Tatar: Explained from the XXI week. History of the Tatar with three-dimensional time. T. I: Steps for Advanced Versioning. Kazan. Rukhiat, pp: 3-11. 